\title{
Status of Bengal Slow Loris Nycticebus bengalensis (Primates: Lorisidae) in Gibbon Wildlife Sanctuary, Assam, India
}

\author{
Nabajit Das ${ }^{1,3}$, J. Biswas ${ }^{1}$, J. Das ${ }^{2}$, P.C. Ray ${ }^{1,3}$, A. Sangma ${ }^{1,3}$ \& P.C. Bhattacharjee ${ }^{1,3}$ \\ ${ }^{1}$ Primate Research Centre NE India, House No-4, Bye Lane No. 3, Ananda Nagar, P.O. Pandu, Guwahati, Assam 781012, India \\ ${ }^{2}$ Wildlife Areas Development and Welfare Trust M.G. Road, Guwahati, Assam 781001, India \\ ${ }^{3}$ Department of Zoology, Gauhati University, Guwahati, Assam 781014, India \\ Email: ${ }^{1}$ nabajit_das@ sify.com, nabajit_das1@ rediffmail.com
}

Date of publication (online): 26 November 2009 Date of publication (print): 26 November 2009 ISSN 0974-7907 (online) | 0974-7893 (print)

Editor: K.A.I. Nekaris

\section{Manuscript details:}

Ms \# 02219

Received 27 May 2009

Final received 30 October 2009

Finally accepted 02 November 2009

Citation: Das, N., J. Biswas, J. Das, P.C. Ray, A. Sangma \& P.C. Bhattacharjee (2009). Status of Bengal Slow Loris Nycticebus bengalensis (Primates: Lorisidae) in Gibbon Wildlife Sanctuary, Assam, India. Journal of Threatened Taxa 1(11): 558-561.

Copyright: () Nabajit Das, J. Biswas, J. Das, P.C. Ray, A. Sangma \& P.C. Bhattacharjee 2009. Creative Commons Attribution 3.0 Unported License. JoTT allows unrestricted use of this article in any medium for non-profit purposes, reproduction and distribution by providing adequate credi to the authors and the source of publication.

Author Details: See end of this article

Author Contribution: ND did research, field work and wrote this paper; JB helped with research designing, field work and assisted with writing; JD provided technical expertise for survey, and literature for this paper; PCR \& AS assisted in field work; PCB supervised the Bengal Slow Loris survey in Assam and GWLS.

Acknowledgments: See end of this article

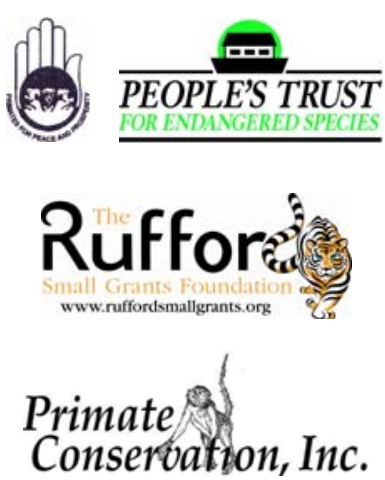

Abstract: Gibbon Wildlife Sanctuary (GWLS) in the Jorhat District of Assam in northeastern India is rich in primate diversity with seven species. The plains alluvial semi-evergreen forest patches with high canopy cover support a variety of fauna. In October-November 2008, we carried out a survey to estimate the population status of Bengal Slow Loris (Nycticebus bengalensis) in GWLS, a species for which little data are available in India, and whose conservation status has only recently been changed from Data Deficient to Vulnerable. We estimated population abundance of 0.18 loris individuals/km using recce-survey transects' method in GWLS.

Keywords: Bengal Slow Loris, Gibbon Wildlife Sanctuary, Nycticebus bengalensis, population abundance

\section{INTRODUCTION}

Among the primates of South and Southeast Asia, the slow lorises (Nycticebus spp.) are amongst the least studied, owing to their nocturnal lifestyle, cryptic nature and relatively small body size (Srivastava \& Mohnot 2001). The Bengal Slow Loris ( $N$. bengalensis) is one of five recognized slow loris species, and was previously considered a subspecies of $N$. coucang (Groves 2001; Roos 2003). The five species, recognized based on genetic and morphological analysis are N. bengalensis, $N$. coucang, N. javanicus, $N$. menagensis and N. pygmaeus (Roos 2003; Chen et al. 2006; Nekaris \& Jaffe 2007; Groves \& Maryanto 2008). The Bengal Slow Loris is distributed throughout northeastern India, Bhutan, Myanmar, Cambodia, Southern China, Laos, northern Thailand and Vietnam (Nekaris \& Bearder 2007). Due to the limited information, the Bengal Slow Loris, endemic to South and Southeast Asia, has been until recently categorized as Data Deficient in the IUCN Red list (2006) and under Schedule I of the Wildlife (Protection) Act of India, 1972. Recently it was up-listed from Appendix -II to Appendix - I of CITES (2007) and it is now considered as Vulnerable (Nekaris et al. 2008; Streicher 2008) in South and Southeast Asia; in South Asia, however, this assessment was made on habitat loss alone since few data are available from the field.

To date limited effort has been devoted to the survey of Bengal Slow Loris population status and threats to it in Assam; indeed virtually nothing is known about its behaviour and ecology in the wild. Although Choudhury in 1992 estimated the population size at 16-17,000 individuals (based on availability of potential habitat), recent publications report that populations of Bengal Slow Loris are declining (Srivastava \& Mohnot 2001; Radhakrishna 2006). Habitat destruction, hunting for food and road accidents are the major threats for this species (Choudhury 1992; Gupta 2001; Radhakrishna 2006).

In the present paper we document the result of a survey of Bengal Slow Loris (Nycticebus bengalensis) in Gibbon Wildlife Sanctuary in the northeastern state of Assam, India. This study represents the first stage of a long-term study of behaviour and ecology of this taxon at this site.

\section{Method}

Study area:

The Gibbon Wildlife Sanctuary $\left(26^{\circ} 40^{\prime}-26^{\circ} 45^{\prime} \mathrm{N} \& 94^{\circ} 20^{\prime}-94^{\circ} 25^{\prime} \mathrm{E}\right)$, is an isolated forest patch surrounded by tea gardens and human settlements. The Gibbon Wildlife Sanctuary (GWLS) was earlier known as "Hollongapar Reserve Forest (RF)", which was set aside as a RF in 1881. The sanctuary had been carved out of the then "Hollongapar RF" named after the dominant tree species - Holong (Diperocarpus macrocarpus). The original area of the RF was 206ha, but in 1896 some of the areas of 
the RF were further de-reserved. Subsequently, more forest areas were added to this RF and by 1997 the total area of the "Hollongpar RF" increased to 2098.62ha. The Government of Assam declared this entire RF area as the Gibbon Wildlife Sanctuary (Image 1) in 1997.

The Sanctuary is now surrounded by tea gardens almost on all sides and by villages on some. GWLS was once contiguous with a large forest tract that extended to Nagaland State. The nearest forest areas of Dissoi Valley Reserve Forests of Nagaland are now separated by a vast stretch of tea gardens presenting a barrier for the effective migration of wild animals. In early days, the forests were covered by sporadic evergreen trees with dense "bojal" bamboos (Pseudodactylum sp). In an attempt to grow well-stocked even-aged regular forest, artificial regeneration was introduced in 1924, leading to regular plantations. The plantation together with the natural vegetation became a well-stocked forest, which encouraged biodiversity in subsequent years. The forest type in the GWLS is Assam plains alluvial semi-evergreen forests, sparsely interspersed with wet evergreen forest patches (Champion \& Seth 1968). The sanctuary is divided into five distinct compartments. The vegetation is composed of several canopy layers; most of the components are evergreen in character.

\section{Survey method}

We adopted the 'recce' (reconnaissance) survey method (Walsh \& White 1999) in conjunction with line transects method (Burnham et al. 1980). The 'recce' method was used to estimate loris encounter rate (MIKE 2006), and has been used in previous studies of closely related species (Nekaris \& Jayewardene 2004; Kumara et al. 2006). Surveys were done at night (1800-0200 hr) from October 28 to November 03, 2008 on foot. Two transects were walked each night and selected randomly to avoid bias, one between $1800-2130 \mathrm{hr}$ and another between 2230-0200 hr (White \& Edwards 2000). Transects were walked at a speed of $1 \mathrm{~km} / \mathrm{h}$.

Due to the high density of elephants (Elephas maximus) within the $\sim 2100$ ha study area, the survey team comprised of three individuals; two were involved in searching both sides of the transect, with one involved in sighting of other animals (i.e. elephant) for security reasons, although for best detection possibilities, a team size of two was desirable (Nekaris et al. 2008). All types of vegetation were searched by Petzl ${ }^{\mathrm{TM}}$ headlamp for detection of Nycticebus, with the aim to detect an orange/red reflection produced from its eye. We used a red filter over the headlamp to observe and confirm the animal, as red light produces less disturbance to loris than white light (Nekaris 2003). On confirmation of loris, data relevant to the

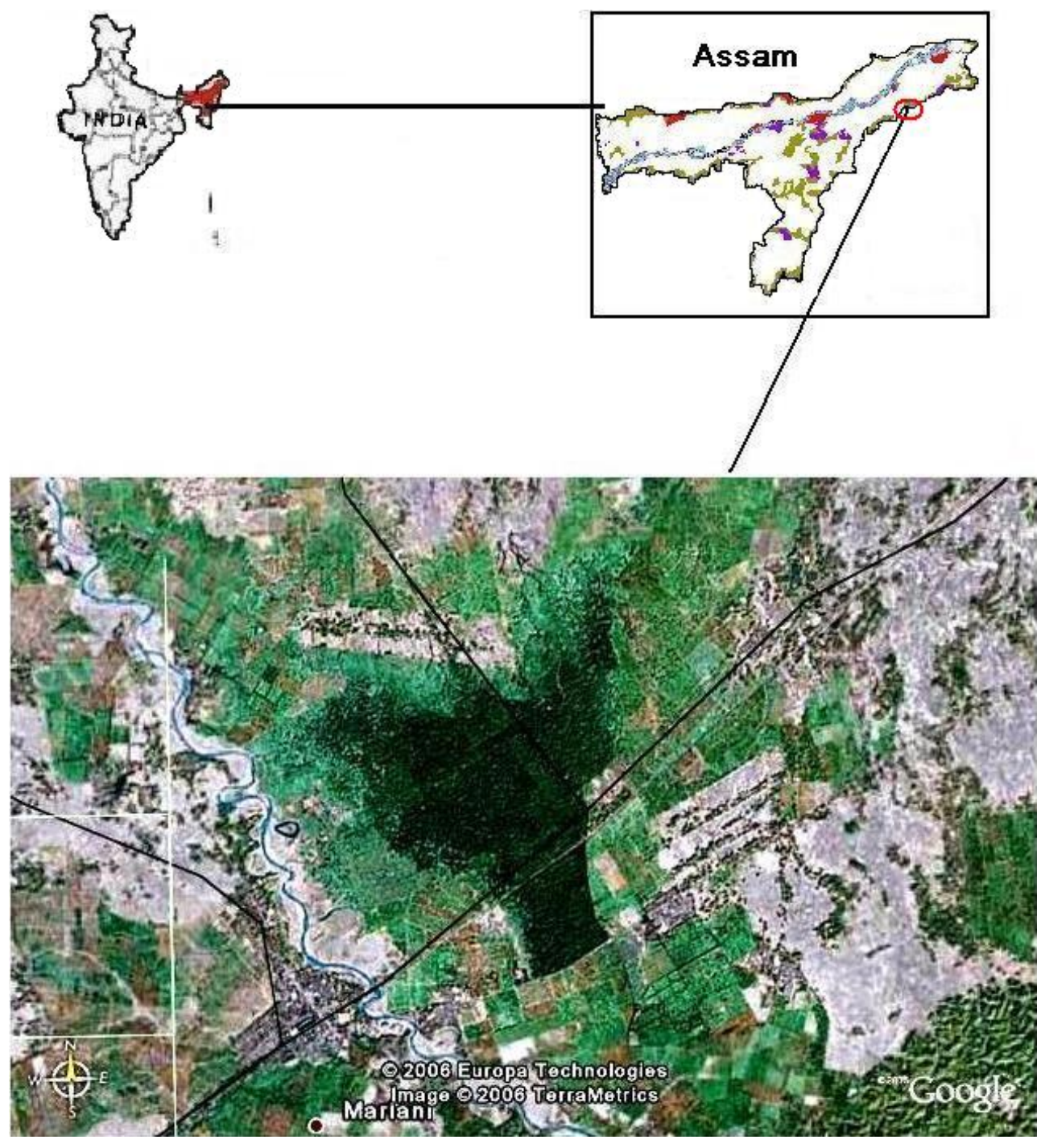

Image 1. Map of Gibbon Wildlife Sanctuary (area in dark green), Assam, India 
Table1. Slow loris encounters in Gibbon Wildlife Sanctuary, Assam, India

\begin{tabular}{|c|c|c|c|c|c|c|}
\hline $\begin{array}{l}\text { Indiv- } \\
\text { idual }\end{array}$ & Tree species with loris & Tree family & $\begin{array}{l}\text { Perching } \\
\text { height }\end{array}$ & Geographic location & $\begin{array}{l}\text { Animal } \\
\text { activity }\end{array}$ & $\begin{array}{l}\text { Time of } \\
\text { sighting (hr) }\end{array}$ \\
\hline 1 & Castonopsis indica & Fagaceae & $12 m$ & $26^{\circ} 41^{\prime} 31^{\prime \prime} \mathrm{N}-94^{\circ} 20^{\prime} 59^{\prime \prime} \mathrm{E}$ & Feeding & 0020 \\
\hline 2 & Magnolia hodgsonii & Magnoliaceae & $10 \mathrm{~m}$ & $26^{\circ} 41^{\prime} 11^{\prime \prime} \mathrm{N}-94^{\circ} 20^{\prime} 46^{\prime \prime} \mathrm{E}$ & Feeding & 2215 \\
\hline 3 & Duabanga sonneritoides & Lythraceae & $12 m$ & $26^{\circ} 40^{\prime} 33^{\prime \prime} \mathrm{N}-94^{\circ} 21^{\prime} 19^{\prime \prime} \mathrm{E}$ & Moving & 2215 \\
\hline 4 & Dipterocarpus retusus & Dipterocarpaceae & $15 \mathrm{~m}$ & $26^{\circ} 40^{\prime} 44^{\prime \prime} \mathrm{N}-94^{\circ} 21^{\prime} 29^{\prime \prime} \mathrm{E}$ & Moving & 0035 \\
\hline
\end{tabular}

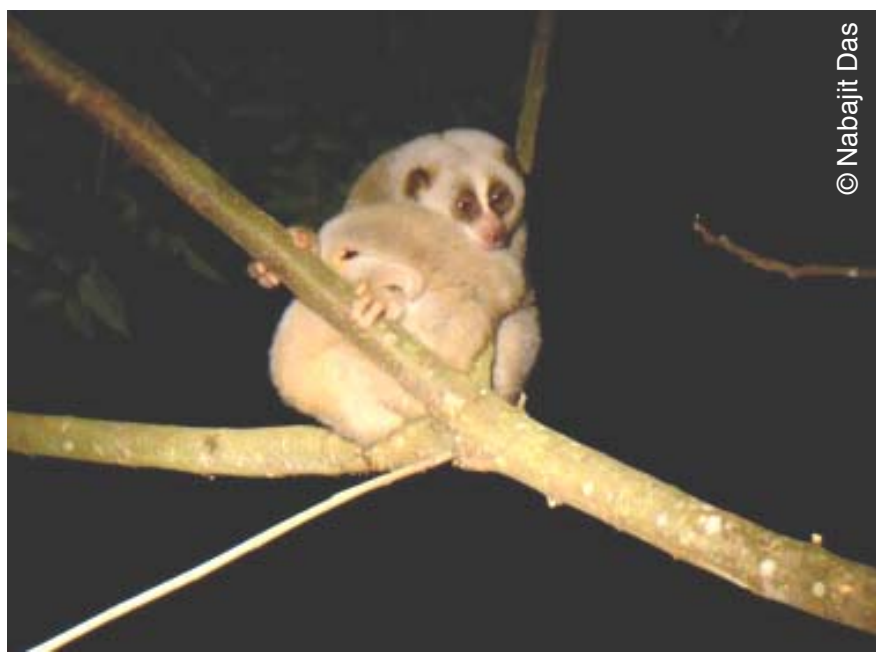

Image 2. An adult Bengal Slow Loris in GWLS in a typical resting posture.

survey including transect length, animal transect distance, number of individuals, distance of the animal from the observer, angle of the animal from the transect line, latitude and longitude, time of detection, activity when first detected, tree height in which it was sighted, tree where it was detected and vegetation type were recorded (Nekaris \& Jayewardene 2004). Photographs of the sighted animal were taken when possible.

\section{Results}

We walked $22.2 \mathrm{~km}$ during seven nights of survey in GWLS. The average length of transect was $3.17 \mathrm{~km}$ per night. Out of the total area covered, $15 \%$ distance was along areas bordering forests and tea estates. The remaining distances walked were in the interior of the reserve. A total of four sightings of lone animals (Image 2; Videos 1-3) were made within the seven survey nights (Table 1 ). The average sighting encounter distance from transect was $6 \mathrm{~m}$ (range $3-10 \mathrm{~m}$ ) and average height at which lorises were sighted was $12.25 \mathrm{~m}$ (range 10-15 m). The abundance estimate of this species in GWLS was calculated to be 0.18 -individual $/ \mathrm{km}$.

On the first two occasions lorises were seen feeding. The other two were found during their movement towards the top of trees probably searching for food. All lorises tried to hide their face away from the white light source. They temporarily froze until we put off the white lights; after some time they moved to a better position within the trees to hide (Video 1).
Table 2: Bengal Slow Loris abundance rate in other areas

\begin{tabular}{lll}
\hline Study site & $\begin{array}{l}\text { abundance estimate } \\
\text { (individuals/km) }\end{array}$ & Surveyor \\
\hline Phou Xang He, Laos & $0.30-0.65$ & Duckworth 1994 \\
Nakay-Nam Theun, Laos & $0.04-0.08$ & Duckworth 1998a \\
Xe Piang, Laos & $0.13-0.27$ & Duckworth et al. 1994 \\
Muang Hom, Laos & $0.10-0.21$ & Evans et al. 2000 \\
Nam Kading, Laos & $0.10-0.22$ & Do \\
Nam Ao, Laos & $0.14-0.30$ & Do \\
Bang Navang, Laos & $0.09-0.20$ & Do \\
Xe Namoy, Laos & $0.40-0.87$ & Do \\
Assam, India & $0.33-0.03$ & Radhakrishna et al. 2006 \\
Trishna \& Sepahijala WLSs, & 0.22 & Swapna et al. 2008 \\
Tripura, India & &
\end{tabular}

\section{Discussion}

The present study reveals an abundance rate of Bengal Slow Loris population allowing comparison with the only other available estimate reported for Assam. S. Radhakrishna and colleagues in 2004 conducted surveys in some parts of Assam, and found 0.03 loris individuals $/ \mathrm{km}$ and in Gibbon Wildlife Sanctuary (Radhakrishna et al. 2006). Our survey estimated an abundance rate of 0.18 individuals $/ \mathrm{km}$, which is slightly higher than that found by Radhakrishna et al. (2006). The present abundance estimate of Bengal Slow Loris in GWLS falls within the ranges as reported by authors in other parts of its distribution area (Table 2). This low encounter rate provides further support to the IUCN Red List status of Vulnerable.

The presence of Bengal Slow Loris in GWLS indicated the possibility of conducting long-term population and behavioural studies. Generally all loris species are sparsely distributed throughout much of their range (Nekaris et al. 2008). Bengal Slow Lorises may occur only in a few isolated populations in some parts of Assam. Despite a serious danger of becoming extinct in many parts of Assam (Radhakrishna et al. 2006), conservation action for this species is still neglected in the western part of its distribution range.

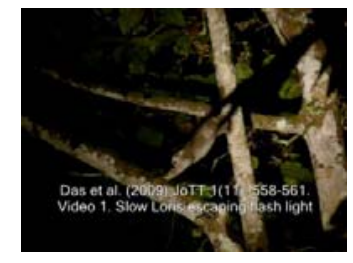

Video 1. Loris escaping from floodlight.

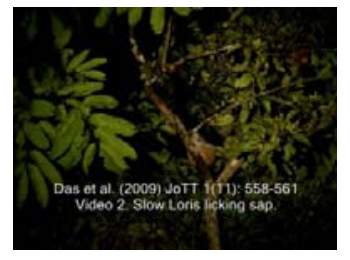

Video 2. Slow Loris licking sap.

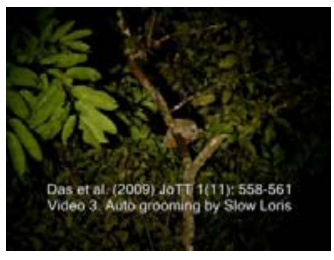

Video 3. Auto grooming by Slow Loris. 


\section{References}

Burnham, K.P., D.R. Anderson \& J.L. Laake (1980). Estimation of density from line transect sampling of biological populations. Wildlife Monograph 72: 1-202.

Champion, S.H.G. \& S.K. Seth (1968). A Revised Survey of The Forest Types of India. The Manager of Publication, Delhi, 404pp.

CITES (2007). CITES Notification to the parties, No. 2007/022, Geneva, 26 July 2007 Web: http://www.cites.org, Website visited on 10 December 2008.

Chen, J.H., D. Pan, C. Groves, Y.X. Wang, E. Narusima, H. Fitch-Snyder, O. Ryder, H.W. Zhang, Y.X. Fu \& Y.P. Zhang (2006). Molecular phylogeny of Nycticebus Infered from Mitochondrial genes. International journal of Primatology 27(4): 0164-0291.

Choudhury, A. (1992). The slow loris (Nycticebus coucang) in Northeast India. Primate Report 34: 77-83.

Duckworth, J.W. (1994). Field sighting of the pygmy loris (Nycticebus pygmaeus) in Laos. Folia Primatol 63: 99-101.

Duckworth, J.W., R.J. Timmins \& R.C.M. Thewlis (1994). Field observations of mammals in Laos, 1992-1993. The Natural History Bulletin of Siam Society 42: 177-205.

Duckworth, J.W. (1998). A survey of large mammals in the central Annamite mountains of Laos. Z Säugetierk 63: 239-250.

Evans, T.D., J.W. Duckworth \& R.J. Timmins (2000). Field observations of larger mammals in Laos, 1994-1995. Mammalia 64: 55-100.

Groves, C. (2001). Primate Taxonomy. Smithsonian Institution Press, Washington, viii+350pp.

Groves, C. \& I. Maryanto (2008). Craniometry of slow lorises (genus Nycticebus) of insular Southeast Asia, pp. 115-122. In: Shekelle, M., C. Groves, I. Maryanto, H. Schulze \& H. FitchSnyder (eds.). Primates of The Oriental Night. LIPI Press, Jakarta.

Gupta, A. (2001): Non-human primates of India - an introduction. In: ENVIS Bulletin: Wildlife and protected areas: Non-human primates of India 1(1): 1-29.

Kumara, H.N., M. Singh \& S. Kumar (2006). Distribution, habitat correlates, and conservation of Loris lydekkerianus in Karnataka, India. International Journal of Primatology 27(4): 941-969.

Monitoring the illegal killing of elephants (MIKE) (2006). Dung survey standards methods for the mike programme, CITES MIKE Programme. Website: http://www.cites.org/eng/prog/ MIKE/index.shtml

Nekaris, K.A.I. (2003). Spacing system of the Mysore slender loris (Loris lydekkerianus lydekkerianus). American Journal of Physical Anthropology 121: 86-96.

Nekaris, K.A.I. \& J. Jayewardene (2004). Distribution of slender lorises in four ecological zones in Sri Lanka. Journal of Zoology 262:1-12.

Nekaris, K.A.I. \& S. K. Bearder (2007). The lorisiform primates of Asia and mainland Africa: diversity shrouded in darkness, pp. 24-45. In: Campbell, C.J., A. Fuentes, K.C. Mackinnon, M. Panger \& S.K. Bearder (eds.). Primates in Pperspective. Oxford University Press, Oxford, UK.

Nekaris, K.A.I. \& S. Jaffe (2007). Unexpected diversity of slow lorises (Nycticebus spp.) within the Javan pet trade: Implications for slow loris taxonomy. Contribution to Zoology 76(3): 187-196.

Nekaris, K.A.I., G.V. Blackham \& V. Nijman (2008). Conservation implications of low encounter rates of five nocturnal primate species (Nycticebus spp.) in Asia. Biodiversity Conservation 17: $733-747$.

Radhakrishna, S., A.B. Goswami \& A. Sinha (2006). Distribution and conservation of Nycticebus bengalensis in northeastern India. International Journal of Primatology 27(4): 971-982.

Roos, C. (2003). Molecular phylogeny of prosimians, langurs and gibbons. Dissertation, Lehrstuhl für Genetik, Wissenschaftszentrum Weihenstephan für Ernährung, Landnutzung und Umwelt, Technical University, Munich.

Srivastava, A. \& S. Mohnot (2001). Distribution, conservation status and priorities for primates in northeast India. ENVIS Bulletin: Wildlife and protected areas: Non-human primates of India 1(1): 102-108.

Streicher, U., M. Singh, R.J. Timmins \& W. Brockelman (2008). Nycticebus bengalensis. In: IUCN 2009. IUCN Red List of Threatened Species. Version 2009.2. <www.iucnredlist.org>. Downloaded on 25 November 2009.

Swapna, N., A. Gupta \& S. Radhakrishna (2008). Distribution survey of bengal slow loris Nycticebus bengalensis in Tripura, northeastern India. Asian Primates Journal 1(1): 37-40.

Walsh, P.D. \& L.J.T. White (1999). What it will take to monitor forest elephant populations. Conservation Biology 13: 1194-1202.

White, L. \& A. Edwards (2000). Methods for assessing the status of animal populations, pp. 91201. In: White, L \& A. Edwards (eds.). Conservation Research in The African Rain Forests: A Technical Handbook, Wildlife Conservation Society: New York.
Author Details: NABAJIT DAS: Currently a PhD scholar studying on the Socio-ecology of Bengal Slow Loris in the protected areas of Assam, India. As a researcher of Primate Research Centre NE India, he is engaged in primate surveys and behaviour studies in northeastern India for the last several years.

Dr. Jinosuo Biswas: Primate Field biologist and programme coordinator of Primate Research Centre NE India. He has been involved in primate field surveys and primate conservation education in northeastern India over 10 years. He has contributed to numerous research papers on primates.

DR. JAYANTA DAS: A large mammal conservationist of northeastern India and currently involved for the Hoolock Gibbon conservation and education.

Parimal Chandra Ray: A researcher of the Primate Research Centre NE India. He is interested in behaviour of primates related to habitat change.

AnJAN SANGma: A researcher of the Primate Research Centre NE India, he is interested in behaviours of nocturnal mammals of northeastern India.

Dr. Parimal Chandra Bhattacharjee: Professor in the Department of Zoology, Gauhati University, is a pioneering worker on the biodiversity of Northeastern India.

Acknowledgments: We thank the Dept. of Environment \& Forest, Govt. of Assam, for providing necessary permission. We specially thank Mr. R. Das, DFO, Jorhat Forest Division; Mr. K. K. Saikia, Range Officer and Mr. Dipak Bordoloi, Beat Officer, Gibbon WLS for allowing us to carry out survey and study at night in the sanctuary and providing all logistic support. We would have achieved little without the generous assistance of the personnel of the Forest Department of GWLS, particularly Deben Borah and Sajan Gonju who acted as field assistants during our survey. We wish to acknowledge Dr. K.A.I Nekaris of Oxford Brookes University, UK for providing the necessary advice, literature and all supports right from the beginning of Bengal Slow Loris studies in this region. We also acknowledge the generous help and support of Mr. Narayan Sarma and others. This work was a part of our study on Bengal Slow Loris in Northeast India, supported by Margot Marsh Biodiversity Foundation, Rufford Small Grants Foundation, Primate Conservation Inc. and People's Trust for Endangered Species. 